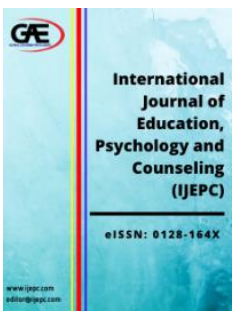

\author{
INTERNATIONAL JOURNAL OF \\ EDUCATION, PSYCHOLOGY \\ AND COUNSELLING \\ (IJEPC) \\ www.ijepc.com
}

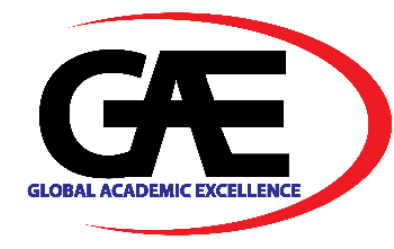

\title{
GUIDANCE SERVICES FOR LEARNERS WITH SPECIAL EDUCATIONAL NEEDS: PERSPECTIVE OF JHS TEACHERS AND COUNSELLORS IN BIRIM CENTRAL MUNICIPALITY, GHANA
}

\author{
Philemon Amaniampong ${ }^{1 *}$, Judith Amankwaa Mensah ${ }^{2}$, Eleanor Bosompemaa Takyi ${ }^{3}$ \\ 1 Department of education, Methodist College of Education, Akim Oda, Ghana \\ Email: philemonamaniampong @yahoo.com \\ 2 Department of education, Methodist College of Education, Akim Oda, Ghana \\ Email: judithamankwaamensah@yahoo.com \\ 3 Department of education, Methodist College of Education, Akim Oda, Ghana \\ Email: awotakyibosm69@gmail.com \\ Corresponding Author
}

\section{Article Info:}

Article history:

Received date: 17.06 .2021

Revised date: 28.06 .2021

Accepted date: 08.07.2021

Published date: 05.09.2021

\section{To cite this document:}

Amaniampong, P., Mensah, J. A., \& Tkayi, E. B. (2021). Guidance Services For Learners With Special Educational Needs: Perspective Of JHS Teachers And Counsellors In Birim Central Municipality, Ghana. International Journal of Education, Psychology and Counseling, 6 (42), 63-73.

DOI: $10.35631 /$ IJEPC.642006

This work is licensed under CC BY 4.0

\begin{abstract}
:
The purpose of the study was to explore guidance services provided for learners with special needs in selected Junior High Schools in Birim Central Municipality. The study adopted the descriptive survey design. The purposive sampling technique was used to select counsellors while the simple random technique was used for teachers with a sample size of 61 . The questionnaire was used to collect the data. The study revealed that teachers have limited knowledge in guidance and counseling and few teachers also counsel learners with special needs even though they were not counselors. Again, it also revealed that appraisal, information, consultation, counseling, and orientation were guidance services provided to learners with special needs but the most common guidance services provided by teachers and counselors to learners with special needs were consultation service, 30(49.2\%), and counselling service, $25(40.1 \%)$. It was recommended that the Municipal guidance and counseling coordinator should collaborate with the special education coordinator and the teachers to organise series of workshops on guidance services for teachers to update their knowledge on counseling.
\end{abstract}

Keywords:

Guidance Service, Special Needs, Learners, Counselors

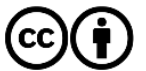




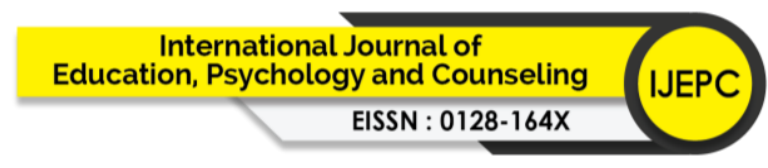

Volume 6 Issue 42 (September 2021) PP. 63-73

DOI 10.35631/IJEPC.642006

\section{Introduction}

Guidance and counselling programmes consist of services designed to facilitate the personalsocial, educational and career development of students. (Namale and Awabi, 2018). The Ministry of Education [MoE] and Ghana Education Service [GES] introduced guidance and counselling units in schools in 1976 to help students to understand and deal with social, behavioural and personal problems. Various education reforms since 1976, including the 2002 Report of the President's Committee on Review of Education Reform in Ghana, and the 2007 education reforms policy have equally reiterated the importance of guidance and counselling in schools (MoE, 2007). UNESCO (2000) observes that the lack of school guidance services increase dropout rates among academically weak students, while Rotondoki (2000) opines that students who lack concentration, self-confidence and constantly fail in their academic endeavours require guidance and counselling support.

The goals of counselling on the other hand are more specific. It includes assisting pupils to overcome their emotional problems (UNESCO, 2012) and change their maladjusted behaviours. It also helps pupils fulfill their potentials and facilitates their overall adjustment, both in school and society. Counseling further enables pupils to make optimum use of available opportunities for the successful achievement of their life goals (Lunenburg, 2010). Pupils with special educational needs and disabilities have unique characteristics like autistic spectrum disorders, emotional disturbance and/or behaviour problems that require extra care. Pupils with speech and language difficulties, hearing impairment, visual impairment and multi-sensory impairment among others also fall within the category of pupils with special educational needs (Greville, 2009, Ocansey and Gyimah, 2016). Essentially, the special characteristics of these pupils often create difficulties in respect of their socialization, reading and writing, comprehension, concentration and physical ability. Another problem facing a number of pupils with special educational needs and disabilities in schools of late is bullying (Hoover and Stenhjem, 2003; Bowman, 2001; Bully B'ware Productions, 2003.

According to Kahveci and Küçük (2016) The counseling services provided to children with special needs or disabilities are significantly outside the average range of general counseling. Many areas of the counseling profession in primary schools have fallen short, with a lack of understanding and appreciation (e.g., attitudes, values, beliefs), a limited repertoire of skills (e.g., techniques, strategies, interventions), and knowledge base. When school counselors do not provide services or develop programs to accommodate the needs of children with disabilities, they deny these students of their expertise and themselves of the enrichment that comes with working with children with disabilities who are challenging, deserving, and responsive (Kahveci and Küçük ,2016). Children with disabilities are often misunderstood and frequently less served by the counseling profession, these children need services just as much as other children (Kahveci and Küçük 2016). As knowledge and experience are obtained for this population, counselors can serve children and their families more fully as intended by legal and professional guidelines. Most counselors, however, do have many of the skills needed to work with these children and their families, such as communication strategies, a background in human, and experience with an array of therapeutic techniques (Kahveci and Küçük 2016). While it is not only Guidance and Counselling alone that determines the students' behaviour and career, the effective use of Guidance and Counselling services help students in putting up good behaviour and choosing a career that would be of benefit to them and the society at large (Yirenkyi, Kyere, and Ofori 2019). But it appears the knowledge level of teachers and the kind of guidance services provided to learners with special needs are not well established. This 


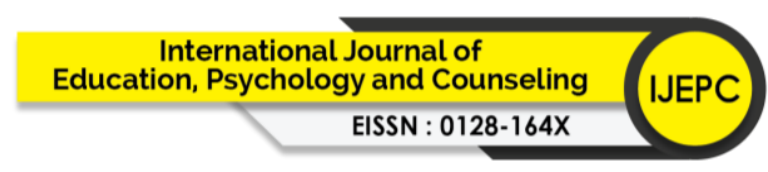

Volume 6 Issue 42 (September 2021) PP. 63-73

DOI 10.35631/IJEPC.642006

informed the researchers to explore the guidance services provided for learners with special needs in selected Junior High Schools in Birim Central Municipality.

\section{Research Questions}

The following research questions were raised to guide the study

1. To what extent' is the knowledge level of teachers on guidance and counseling in Birim Central Municipality?

2. To what extent are the guidance services provided to learners with special needs in Birim Central Municipality?

\section{Review of Related Literature}

Guidance and Counselling support the effective management and administration of schools, achievement of the nation's aims and objectives regarding the purposes of education nationally and internationally (Yirenkyi, Kyere, and Ofori 2019). Despite the numerous benefits of guidance and counseling to learners including learners with special needs, it does not realize this benefits without a challenge. Ogunlade and Akeredolu (2012) discovered in a study that most counselors in the school system are untrained and this can affect efficiency and the ability to woo more clients. Eliamani, Richard, and Peter, (2014) also found non-professional counseling greatly affected access to counselling services. The lack of trained counsellors in Tanzanian schools, they found, denied and discouraged many students accessing professional guidance services.

The guidance services that are provided in schools include orientation, appraisal, information, consultation, counselling, placement, and evaluation services (Oladele, 2007; Taylor and Buku, 2006, Namale and Awabil, 2018). These services are briefly described below:

- Orientation service: It is provided to assist students to get familiar with a new school, its history, its rules and policies and its vast opportunities with the view to making them feel emotionally secured and better adjusted (Oladele, 2007). Chireshe (2006) added the orientation service provides students with study skills and explains to them the school curriculum.

- Appraisal service: This service involves gathering, organizing and interpreting information or data about the student to enable him/her to understand himself or herself (Fafunwa \& Akinpelu, 2008). When the student knows and understands his or her aptitudes, abilities, interests, strengths and weaknesses he or she can make reasonable choice from different alternatives at his or her disposal. Information about the student is usually collected through interviews and written reports from parents and teachers and the use of psychological tests. The appraisal is usually concerned with academic, personal and social development of the pupil/student. All the data needed for appraising a pupil are usually kept in the Pupil Cumulative Record Card. This is the record that gives most of the background information about a pupil who needs counselling (Oladele, 2007).

- Information service: This service is designed to provide students with a greater knowledge of educational, vocational, personal-social opportunities so that they may make better, informed and realistic choices and decisions about their educational and vocational plans (Oladele, 2007). 


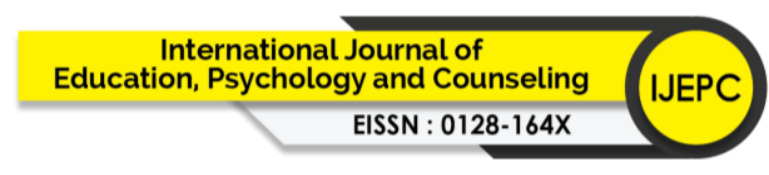

Volume 6 Issue 42 (September 2021) PP. 63-73

DOI 10.35631/IJEPC.642006

- Consultation service: It is an activity engaged in by a counsellor in order to help a student address a need through a third party such as a teacher or parent (Gibson and Mitchell, 1990). The counsellor serves as a consultant to the third party with the view to equipping him or her with knowledge and skills so that the needs of the student could be met adequately.

- Counselling service: This service is primarily designed to strengthen the individual's ability to solve his or her own problems. A small group of students with similar concerns can also benefit from counselling. Both trained counsellors and paraprofessionals provide counselling services to students in Ghana. Placement service: This service enables students to be admitted into a school of their choice. It also assists school leavers to be employed in jobs they are best fitted for (Awabil and Kankpog, 2011).

- Evaluation service: It determines the extent to which services such as orientation counselling, consultation and information services are effectively implemented in schools. Essuman (2001) and Chireshe (2006) opined that once guidance services have been offered they need to be evaluated. (Awabil and Kankpog, 2011) posited that evaluation is not of direct benefit to students but for the benefit of school officials and the community. Namale and Awabil, (2018). Conducted a study on evaluation of guidance services in senior high schools in Gomoa West District in the Central Region of Ghana, the results indicated that the appraisal service was effectively implemented while the information, consultation and counselling services were not effectively implemented. It also revealed that gender is not a significant determinant of students' evaluation of the information, consultation and counselling services. Again, Yirenkyi, Kyere and Ofori (2019). Found out that $60 \%$ of the counsellors were untrained, while about half of the schools (53.3\%) did not have counselling offices at Manhyia Sub Motropolis The findings also revealed that counselling and orientation were the most guidance services operating in the schools.

Wijaya, Husniah, Taherong, Nuryadin, Hanifa and Ichsani (2019) study on professional competency levels teacher guidance and counseling and counselor school. The research method used was a quantitative descriptive approach, the population in this study consisted of 79 counseling teachers or counselors who actively carry out counseling and counseling services at school. Results show that for dimensional competency of mastering the concepts and assessment prerequisites to understand the conditions, needs, and problems of advice categorized as still low was at $43.04 \%$ and high only $27.85 \%$. For competency of mastering the theoretical and practical framework of the Guidance and Counseling category classified as quite high was $36.71 \%$ and the lowest was $30.38 \%$. Designing a high category of Guidance and Counseling Program competency was $50.63 \%$ and a minimum of $36.71 \%$. The competency of assessing the process and results of Guidance and Counseling activities and competency of having awareness and commitment to professional ethics was $70.89 \%$ and lowest $8.86 \%$. Mastering the concepts and praxis of research in Guidance and Counseling competency was still dominant at $72.15 \%$, and the highest was 11.39\%. Again, Ocansey and Gyimah (2019) study on guidance and counselling for pupils with special educational needs in Accra, Ghana: implications for inclusive education. Both quantitative and qualitative methods was used for the study. The Quantitative data was analysed using descriptive statistics, specifically, frequencies and percentages while in the qualitative analysis, the thematic approach was used. The findings regarding available school guidance services were encouraging. Pupils essentially recorded their satisfaction with the staff's immense roles in providing them with relevant support services.

Copyright $\odot$ GLOBAL ACADEMIC EXCELLENCE (M) SDN BHD - All rights reserved 


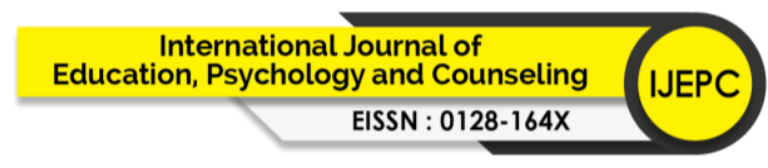

Volume 6 Issue 42 (September 2021) PP. 63-73

DOI 10.35631/IJEPC.642006

Asamari (2015) study on the provision of guidance and counselling services in colleges of education in Northern Ghana, the study established that orientation, information, appraisal, counselling and placement services were the major guidance and counselling services provided at the colleges.

\section{Methodology}

\section{Design}

The study adopted the descriptive survey design. This design has been recommended as appropriate for studies which involve a cross section of respondents or subjects with almost similar characteristics (Amin, 2005; Fraenkel and Wallen, 2006). This research design will therefore aid the researchers determine the exact guidance services given to learners with special needs in Birim Central Municipality. The population for the study was 72 which comprised all teachers and counsellors in the six selected Junior High School in Oda Township in the Birim Central Municipality. The sample size was 61, comprised of 6 counselors and 55 teachers. The breakdown of the selected schools are: Freeman Methodist JHS, 11, Wesley Methodist JHS 11, Old Town Methodist JHS 8, Anglican JHS 12, Presby Girls JHS 10, and Islamic JHS 9.

Purposive and simple random sampling technique were used to select the respondents. The purposive sampling was used to select counsellors while the simple random was used to select the teachers. Johnson and Christensen, (2004) stated that, purposive sampling technique solicits from persons with specific characteristics to participate in a research study. Purposive sampling was used to select the counselors because the counselors were in the schools with the learners and were respondents who could give the right information for the study. The convenience sampling was also used to select the schools who have counselors and also doubled as teachers. A sample of 61 respondents were selected comprising of teachers and counselors.

\section{Data Collection Instrument}

Self-designed questionnaire was used as the main instrument for the study. There were fifteen close-ended questions on the guidance services for the study, namely, orientation service, appraisal service, information service, consultation service and counselling service. The items on each guidance service were structured along a four point Likert-type, scale ranging from (Strongly Agreed, SA), (Agree, A), (Disagree, D) and (Strongly Disagreed, SD) The questionnaire was content-validated by two experts in the field of guidance and counselling and special education in the department of education of Methodist College of Education. The questionnaire was designed based on the four point Likert scale, on the questionnaire, and took the form of agreement ranging from 4=Strongly Agree (SA), 3=Agree (A), 2=Disagree (D) and $1=$ Strongly Disagree (SD) The questionnaire cover all the variables of the study. According to Cohen, Manion and Morrison (2007), close-ended questions are quick to compile and straight forward to code, and do not discriminate unduly on the basis of how articulate the respondents are.

\section{Data Collection Procedure}

Permission was sought from the headmasters in the various schools used of the study. The purpose of the study was explained to the respondents to allay their fears, as far as giving information about the guidance services in their schools was concerned. Some teachers in the schools helped the researchers to distribute the questionnaire to their colleague teachers. The 
Volume 6 Issue 42 (September 2021) PP. 63-73

DOI 10.35631/IJEPC.642006

respondents answered and returned all the questionnaires. The return rate was, therefore, hundred percent.

\section{Data Analysis}

Data gathered from the questionnaires administered were first organized, coded and categorized. Following this, Descriptive statistics, in the form of percentages and frequencies, were employed to analyze the collected data. Frequency tables were constructed in line with the variables raised in the research questions to support the data analysis.

\section{Findings}

\section{Knowledge Level of Teachers in Guidance and Counseling}

Table 1: The Frequency Distributions of Teachers' and Counsellors' Responses to the Questionnaire Items 1-4

\begin{tabular}{llllc}
\hline STATEMENT & AGREE & $\%$ & DISAGREE & $\%$ \\
$\begin{array}{l}\text { Q1 I studied a course in guidance and counseling for } \\
\text { one semester at college or university }\end{array}$ & 100 & 0 & 0 \\
$\begin{array}{l}\text { Q2 I studied guidance and counseling as a full course } \\
\text { at the university }\end{array}$ & 29.5 & 43 & 70.5 \\
$\begin{array}{l}\text { Q3 I did not study guidance and counseling as a } \\
\text { course but counsel learners }\end{array}$ & 39.3 & 37 & 60.7 \\
$\begin{array}{l}\text { Q4. I studied guidance and counseling through in- } \\
\text { service training or workshops from counsellors }\end{array}$ & & 40.9 & 36 & 59.1
\end{tabular}

From the results of table 1, all the respondents agreed to the statement that they studied a course in guidance and counseling for one semester at college or university. The statistics show that $61(100 \%)$ of respondents agreed to the statement. With regards to the second statement, few of the respondents studied guidance and counseling as a full course at the university. The table shows that $18(29.3 \%)$ agreed and $43(70.5 \%)$ disagreed with the statement.

Again, 24 respondents representing (39.3\%) agreed that they did not studied guidance and counselling as a course but they counsel learners while $37(60.7 \%)$ disagreed with the statement. Finally, with regards to the statement I studied guidance and counseling through inservice training or workshops from counsellors, 25 of the respondents representing $(40.9 \%)$ agreed to the statement while 36 representing (59.1\%) disagreed with the statement.

Extent to Which Guidance Services Are Provided to Learners with Special Needs

Table 2: The Frequency Distributions of Teachers' and Counsellors' Responses to the Questionnaire Items 1-11.

\begin{tabular}{lllll}
\hline STATEMENT & SA & A & D & SD \\
& & & & \\
\hline Appraisal Service & 15 & 18 & 16 & 12 \\
& $(24.6 \%)$ & $(29.5 \%)$ & $(26.2 \%)$ & $(19.7 \%)$ \\
\hline
\end{tabular}

Copyright $\odot$ GLOBAL ACADEMIC EXCELLENCE (M) SDN BHD - All rights reserved 
1.Teachers use tests to assist learners with special needs to understand themselves

2.Learners with special needs are made aware of their abilities, interests and values with regard to job opportunities.

\section{Information service}

3.learners with special needs are informed about secondary circle institutions and their mode of entry, entry requirements, programmes.

4.The school counsellor and teachers assists learners with special needs to develop their social skills by the use of newspapers, magazines, brochures etc.

Consultation service

5. Parents and teachers exchange ideas for the benefit of learners with special needs

6.The school counsellor meets teachers to find ways of improving the learning skills of learners with special needs

Counseling service

7.The school counsellor helps students to get over their personal problems

8.learners with special needs are assisted by and teachers to resolve their emotional difficulties.

Orientation service

9.Counselors and teachers assist learners with special needs to be familiar with the history and partners of the school.

10. Counselors and teachers assist learners with special needs to be familiar with school rules and regulations.

11. Counselors and teachers offered guidance services only in the schools when the need arises
20
18
12
11
(32.8\%)
$(29.5 \%)$
(19.7\%)
(18.0\%)

25

$(40.9 \%) \quad(26.2 \%)$

11

9

(18.1\%) (14.8\%)

$\begin{array}{llll}18 & 22 & 11 & 10 \\ (29.5 \%) & (36.0 \%) & (18.1 \%) & (16.4)\end{array}$

30

20

6

5

$\begin{array}{llll}(49.2 \%) & (32.8 \%) & (9.8 \%) & (8.2 \%)\end{array}$

$\begin{array}{llll}29 & 16 & 9 & 7\end{array}$

$\begin{array}{llll}(47.5 \%) & (26.2 \%) & (14.8 \%) & (11.5)\end{array}$

$20 \quad 23$

8

(32.8\%) (37.7)

(13.1)

10

9

(16.4\%)

\section{9}

25

$(14.8 \%) \quad 8$

(31.2\%) (40.9\%)

13

$15 \quad 23$

(21.3\%) $\quad 10$

(24.6\%) (37.7\%)

13

$\begin{array}{ll}15 & 24 \\ (24.6 \%) & (39.3 \%)\end{array}$

(21.3\%) 9

(14.8\%)

12

15

22

(36.0\%) 12

(19.7\%) (24.6\%)

(19.7\%)

The table 2 shows the frequency distributions of teachers and counselors responses to questionnaire items 1-11. The first item was to find out from teachers whether teachers use tests to assist learners with special needs to understand themselves. A total of $15(24.6 \%)$ 


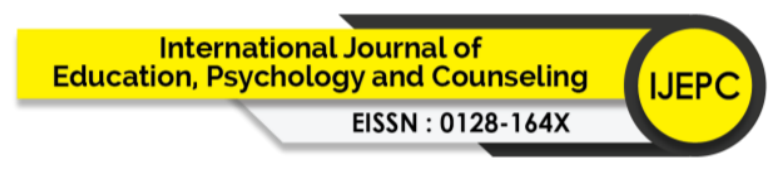

Volume 6 Issue 42 (September 2021) PP. 63-73

DOI 10.35631/IJEPC.642006

teachers and counselors strongly agreed, 18(29.5\%) agreed, 16(26.2) and 12(19.7\%) strongly disagreed with the statement. This is an indication that $18(28.5 \%)$ teachers and counsellors strongly agreed as against $12(19.7 \%)$ use tests to assist learners with special needs to understand themselves. With regards to item 2, which was to find out whether learners with special needs are made aware of their abilities, interests and values with regard to job opportunities, a total of 20(32.8\%) strongly agreed, 18(29.5\%) agreed, 12(19.7\%) disagreed and $11(18.0 \%)$ strongly disagreed with the statement. This is an indication that quit a number of teachers and counsellors strongly agreed that learners with special needs are made aware of their abilities, interests and values with regard to job opportunities. The first two items are in relation to appraisal service.

With regards to information service, item 3 and 4 were used to cater for it. Item 3 was to find out whether learners with special needs are informed about secondary circle institutions and their mode of entry, entry requirements, programmes, a total of 25(40.9\%) strongly agreed, 16 $(26.2 \%)$ agreed, $11(18.1 \%)$ disagreed and $9(14.8 \%)$ strongly disagreed with the statement. This shows that quite a number of teachers and counsellors agreed with the statement. Item 4 was to find out whether counselors and teachers assist learners with special needs to be familiar with school rules and regulations, a total of 18(29. 5\%) strongly agreed, 22(36.0\%) agreed, $11(18.1 \%)$ and $10(16.4 \%)$ strongly disagreed with the. This shows that quite a number of teachers and counsellors agreed with the statement which means that they provide information service to learners with special needs

Regarding consultation service, item 5 and 6 were used to addressed it. Item 5 was to find out whether parents and teachers exchange ideas for the benefit of learners with special needs, a total of 30(49.2\%) strongly agreed, 20(32.8\%) agreed, 6(9.8\%) disagreed and 5(8.2\%) strongly disagreed with the statement. Item 6 was to find out whether the school counsellor meets teachers to find ways of improving the learning skills of learners with special needs, a total of $29(47.5 \%)$ strongly agreed, 16(26.2\%) agreed, 9(14.8\%) disagreed and 7(11.5\%) strongly agreed with the statement. This indicates that majority of teachers and counsellors provide consultation service to learners with special needs. With regards to counselling service, items 7 and 8 were used to respond to it. Item 7 was to find out whether school counsellors help students to get over their personal problems, a total of 20(32.8\%) strongly agreed, $23(37.7 \%)$ agreed, $8(13.1 \%)$ disagreed and 10(16.4\%) strongly disagreed with the statement. Item 8 was to find out whether learners with special needs are assisted by counselors and teachers to resolve their emotional difficulties, a total of 19(31.2\%) strongly agreed, 25(40.9) agreed, $9(14.8 \%)$ disagreed and $8(13.1 \%)$ teachers and counsellors strongly agreed with the statement. This shows that quite a number of teachers and counsellors agreed that they provide counselling service to learners with special needs.

Again, items 9 and 10 were used to respond to orientation service. Item 9 was to find out whether counselors and teachers assist learners with special needs to be familiar with the history and partners of the school. A total of 15(24.6\%) strongly agreed, 23(37.7\%) agreed, $13(21.3 \%)$ disagreed and $10(16.4 \%)$ strongly disagreed with the statement. Item 10 was to find out whether counselors and teachers assist learners with special needs to be familiar with school rules and regulations, a total of 15(24.6\%) strongly agreed, 24(39.3\%) agreed, 13(21.3\%) disagreed and $9(14.8 \%)$ strongly disagreed with the statement. This means that quite number of teachers and counsellors agreed that they provide orientation service to learners with special needs. 


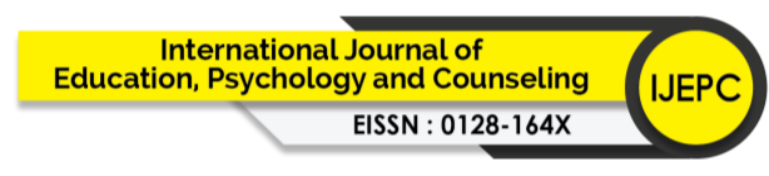

Volume 6 Issue 42 (September 2021) PP. 63-73

DOI 10.35631/IJEPC.642006

Finally, item 11 wants to find out whether counselors and teachers offered guidance services only in the schools when the need arises, a total of 12(19.7\%) strongly agreed, $15(24.6 \%)$ agreed, 22(36\%) disagreed and 12(19.7\%) strongly disagreed with the statement. This indicates that quite number of respondents disagreed that teachers and counsellors only offer guidance services when the need arises.

In effect, appraisal, information, consultation, counseling and orientation were guidance services provided to learners with special needs but the most common guidance services provided by teachers and counselors to learners with special needs were consultation service, and counselling service

\section{Discussion}

The research question one was on knowledge level of teachers in guidance and counseling. The study revealed that, all the respondents have studied a course in guidance and counseling for one semester at college or university. On item two, it was revealed that only $18(29.5 \%)$ studied guidance and counseling as a full course at the university as against $43(70.5 \%)$ who did not studied guidance and counseling as a full course at college or university. This means that majority of teachers have limited knowledge in guidance and counseling. This corroborates with the view of Kahveci and Küçük (2016) that many areas of the counseling profession in primary schools have fallen short, with a lack of understanding and appreciation, a limited repertoire of skills and knowledge base. It again corroborates with some aspects of Wijaya, Husniah, Taherong, Nuryadin, Hanifa and Ichsani (2019) study which shows that for dimensional competency of mastering the concepts and assessment prerequisites to understand the conditions, needs, and problems of advice categorized as still low was at $43.04 \%$ and high only $27.85 \%$. For competency of mastering the theoretical and practical framework of the Guidance and Counseling category classified as quite high was $36.71 \%$ and the lowest was $30.38 \%$.

On item 3, it revealed that 24(39.3\%) did not study guidance and counseling as a course but counsel learners while $37(60.7 \%)$ disagreed. This shows that only few of the respondents' counsel learners with special needs even though they were not trained counselors. This is in contrast with Yirenkyi, Kyere and Ofori (2019) whose study found out that $60 \%$ of the counsellors were untrained, while about half of the schools $(53.3 \%)$ did not have counselling offices at Manhyia Sub Motropolis and also Ogunlade and Akeredolu (2012) also discovered in a study that most counselors in the school system are untrained and this can affect efficiency and the ability to woo more clients. Though with regards to the current study, some teachers agreed with the statement that they were not counsellors but they counsel learners but majority disagreed with the statement. With regards to item 4 majority $36(59.1 \%)$ disagreed with the statement that they studied guidance and counseling through in-service training or workshops from counsellors.

Research question two was on extent to which guidance services were provided to learners with special needs. The study revealed appraisal, orientation, information, consultation and counseling services for learners with special needs. This confirms with Asamari (2015) study that, orientation, information, appraisal, counselling and placement services were the major guidance and counseling services provided at the colleges. It also revealed that the most common guidance services provided by teachers and counselors were consultation service, 30(49.2\%), 29(47.5\%) and counselling service, 25(40.1\%), 23(37.7\%). This supports Yirenkyi, 


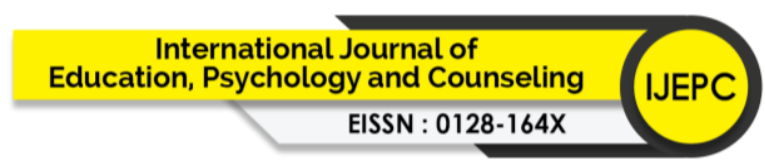

Volume 6 Issue 42 (September 2021) PP. 63-73

DOI 10.35631/IJEPC.642006

Kyere and Ofori (2019) whose findings revealed that counselling and orientation were the most guidance services operating in the schools. Though the current study revealed consultation and counseling services as most operating guidance services but the previous study revealed counseling and orientation, which means that it was only counseling service that was most operating service in both studies. This is in disagreement with Namale and Awabil, (2018) whose study indicated that the appraisal service was effectively implemented while the information, consultation and counselling services were not effectively implemented. Again, Ocansey and Gyimah (2019) findings show that the available school guidance services were encouraging. Pupils essentially recorded their satisfaction with the staff's immense roles in providing them with relevant support services. Though the previous study did not reveal specifically the kind of guidance services provided in the schools but indicated that the guidance services provided were encouraging.

\section{Conclusion and Recommendation}

It has been established that teachers have some knowledge in guidance and counseling but the knowledge is limited and few teachers also counsel leaners with special needs even though they were not counselors. It has also shown that pupils with special needs were not left out but teachers and counselors provide them with some guidance services. Based on the findings, it was recommended that the Municipal guidance and counseling coordinator should collaborate with special education coordinator and the teachers to organise series of workshops on guidance services for teachers to update their knowledge on counseling.

\section{References}

Awabil, G., \& Kankpog, E. B. (2011). Evaluation of guidance services in junior high schools in the Jirapa-Lambussie District of Ghana: Students' perspective. Journal of Educational Research and Development, 6(3), 83-89.

Bowman, D. H. (2001). At school, a cruel culture. Education Week, 20(7), 1-17. http://www.edweek.org/ew/ew_printstory.cfm?slug=27taunts.h20

Bully B'ware Productions, (2003). Bullying and teasing of youth with disabilities: creating positive school environments for effective inclusion. http://www.bullybeware.com/moreinfo.html

Chireshe, R. (2006). An assessment of the effectiveness of school guidance and counselling services in Zimbabwean secondary schools (Electronic version). University of South $\mathrm{s}$ Africa, South Africa

Cohen, L., Manion, L., \& Morrison, K. (2007). Research methods in education (6th ed.). London: Routledge.

Essuman, J. K. (2001). A review of educational studies in guidance and counselling in secondary schools in Ghana. Ghana Journal of Psychology, 1, $72-88$.

Fafunwa, S. B., \& Akinpelu, D. (2008). Provision of guidance services in senior high schools in Lagos State: Evaluative study. Ghana Journal of Education and Teaching, 6, 9 -18 .

Fraenkel, J., \& Wallen, N. (2006). How to design and evaluate research in education (6th ed.). New York: McGraw-Hill.

Greville, E. (2009). Including pupils with special educational needs in schools in Ireland. Organisation for Economic Co-operation and Development (OECD), Ireland, CELE Exchange on www.oecd.org/publishing/corrigenda

Gibson, R. L., \& Mitchell, M. H. (1990). Introduction to counseling and guidance (3rd ed.). New York: Macmillan Publishing Company 


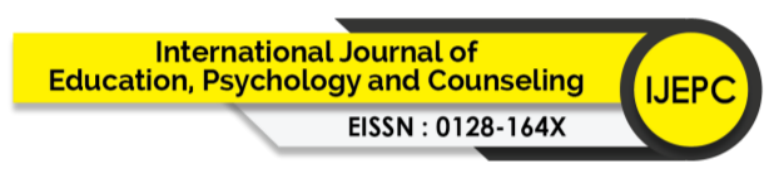

Volume 6 Issue 42 (September 2021) PP. 63-73

DOI 10.35631/IJEPC.642006

Lunenburg, F. C. (2010). School guidance and counselling services (Electronic Version). schooling, http://www.nationalforum.com

Johnson, B., \& Christensen, L. (2004). Educational research: Quantitative, qualitative and mixed approaches (2nd Ed.). Boston, MA: Pearson Education, Inc.

Eliamani, M.P., Richard, M.L., \& Peter. (2014). Access to guidance and counseling services and its influence on Studentse ${ }^{\text {ee }}$ school life and career choice. African Journal of Guidance and Counselling, 1 (1), 007-015.

Ogunlade, J.O \& Akeredolu, S.A. (2012). Influence of counselling on career preference among secondary school students in Ekiti State, Nigeria. Journal of Sociology, Psychology and Anthropology in Practice, 4, 3.

Ocansey, S. K. \& Gyimah, E. K. (2019). Guidance and counselling for pupils with special educational needs in Accra, Ghana: implications for inclusive education. Teacher Education Through Flexible Learning, 1(1), 104-121.

Ocansey, S. K. \& Gyimah, E. K. (2016). Counselling needs of pupils with special educational needs and disabilities in the Greater Accra Region of Ghana: implications for inclusive education in Ghana. Journal of Education and Practice. 7(21), 99-109.

Oladele, J. O. (2007). Guidance and counselling: A functional approach (4th ed.). Lagos: Johns- Lad Publishers Ltd.

Namale, M. K., \& Awabil, G (2018). Evaluation of guidance services in senior high schools in Gomoa West District in the Central Region of Ghana. Journal of Education and Practice. 9(17), 23-30.

Rutondoki, E. N. (2002). Guidance and Counselling., Institute of Adult and Continuing Education. Makerere University.

Taylor \& Buku (2006). Basics in Guidance and Counselling (2nd ed.). Department of Psychology \& Education, University of Education, Winneba.

UNESCO (2000). Guidance and counselling development (Module 8). Botswana

Wijaya, R.S., Husniah,W.D., Taherong,R., Nuryadin, C., Hanifa,L and Ichsani, N. (2019). Professional competency levels teacher guidance and counseling and counselor school. IOP Conference Series: Earth and Environmental Science,1-7.

Yirenkyi. C. A., Kyere, E. A., \& Ofori, K. N. (2019). Evaluation of guidance and counselling practices in schools: A case study of Manhyia Sub-Metropolis, Ghana. International Journal of Education, Psychology and Counseling, 4(28), 